\title{
PODCASTY A ICH POTENCIÁL V ŠTYLISTIKE ${ }^{1}$
}

\section{Podcasts and their Potential in Stylistics}

Keywords: podcasts, linguistic interpretation, style, genre, media communication

Contact: Univerzita Komenskéhov Bratislave; kristina.piatkova@uniba.sk

V predloženej štúdii sa venujeme relatívne novému a mladému mediálnemu formátu - podcastu. Sústredíme sa na vznik podcastov, ich charakteristické znaky a etablovanie sa v slovenskej publicistike. Podcasty skúmame z hl'adiska lingvistiky a konkrétne to, aké typy mediálnych komunikátov prostredníctvom podcastov vznikajú.

Tvorba printových a audiovizuálnych médií sa v súčasnosti výrazne spája $\mathrm{s}$ aktívnou i pasívnou participáciou percipientov $\mathrm{v}$ masmediálnom diskurze na internete. Produkty profesionálnych novinárov sa začali na webových stránkach (novín, časopisov, rozhlasových a televíznych staníc) prelínat's textami blogerov a videami vlogerov ${ }^{2}$. Nejde o pôvodné masmédiá, ale technický pokrok a rozmach elektronických médií na internete spustili éru podcastingu.

Podcast je zvukové vysielanie na internete, ktoré si môže percipient vypočut' alebo stiahnut' na smartfón, resp. iné médium. Ide o epizodické série digitálnych súborov, ktoré majú rôznu periodicitu (Tvrdoň 2019). Podcasty vychádzajú denne, týždenne alebo mesačne. Na Slovensku sa produkujú spravodajské podcasty, napr. Dobré ráno - denný podcast dennika SME; Podcast Dennika $N$ a i. Rozhlasové a televízne stanice i časopisy tiež tvoria svoje vlastné podcasty, ktoré sú analogicky ako relácie rozdelené do viacerých kategórií podl'a zamerania, akými sú šport, veda, umenie, cestovanie, zdravie, životný štýl, napr. podcasty relácii RTVS, podcasty časopisu .týždeň. Podcasty sú v slovenskom i zahraničnom mediálnom priestore diferencované aj podl'a adresáta (pre ženy napr. Medzi nami - týždenný podcast denníka SME; Volafka - rozhovor so zaujímavými ženami z Čiech a Slovenska; V̌̌enskom rode; Women

\footnotetext{
${ }^{1}$ Štúdia vznikla v rámci riešenia projektu VEGA 1/0553/18 Pragmatické a gramatické principy jazyka so zretelom na kultivovanie jazykovej praxe.

${ }^{2}$ Vloger tvorí video blogy - internetové osobné „zápisníky“, v ktorých vyjadruje svoje názory, myšlienky na rôzne produkty, služby, spoločenské, kultúrne či politické dianie. Stali sa vyhl’adávaným zdrojom informácií v oblasti marketingu.
} 
Wanting More a i.; pre mužov napr.: mužom.sk; Silný výber; Nový muž; pre deti napr. Rozhlasové leporelo; Halabala; Český rozhlas - Pro děti a i.).

Podcasty v porovnaní s rozhlasovým vysielaním fungujú na offline báze, teda nie sú živým vysielaním. Vyznačujú sa bezprostrednost'ou a neformálnost’ou. Poslucháč neprispôsobuje svoje aktivity programovej ponuke rádia či iného média, ale naopak podcasty sa „prispôsobujú“ každodennosti poslucháčov. Na rozdiel o rozhlasového vysielania sú osobnejšie a jednotlivec si sám vyberá, čo a kedy bude počúvat'. Sú dostupné aj pri takých aktivitách, ako je cestovanie verejnou dopravou, behanie či prechádzka so psom (Prokopčák 2019).

\section{Typy podcastov a ich tvorcovia}

Podcasty, ktoré vznikajú vo väčších médiách, ako sme spomínali vyššie, najčastejšie tvoria redaktori, moderátori denníkov, týždenníkov, televíznych relácií a pod. Moderátor reprezentuje médium, ktoré zastupuje (rozhlas, televíziu, časopis) a jeho úloha je náročná - mal by byt’ odborne vzdelaný, spoločensky rozhl’adený, nestranný (pozri Müllerová 1999: 169-170). Podcasty tvorené odborníkmi s praxou sa vyznačujú pripravenost'ou (môžu mat' aj podobu písaného podkladu), oficiálnost'ou, verejnost'ou. Majú štandardizovaný úvod, v ktorom moderátor spomenie rámcové údaje (dátum, kto má meniny, stručnú predpoved' počasia, odkaz na aktuálnu dennú situáciu), názov podcastu a kto poslucháča podcastom sprevádza.

\section{Ukážka č. $1^{3}$ :}

\footnotetext{
${ }^{3}$ [ ] hranaté zátvorky používame na vyznačenie simultánneho vyslovenia častí replík;

VELKÉ PÍSMO takto zaznamenávame časti repliky, ktoré boli vyjadrené hlasnejšie v porovnaní s okolitými čast’ami;

- $\quad$ znak stupňa obklopuje čast’ výpovede, ktorá bola vyjadrená tichšie ako časti, ktoré ju obklopujú;

Podčiarknutie vyjadruje zdôraznenie;

$>\quad$ medzi znaky viac a menej umiestňujeme čast’ repliky, ktorá bola vyslovená výrazne rýchlejšie ako okolité časti;

) ( medzi zátvorky v obrátenom poradí umiestňujeme repliku alebo čast’ repliky, ktorá bola vyslovená výrazne pomalšie ako okolité časti;

(.) vel’mi krátku pauzu, avšak predsa pocit’ovanú ako príznakovú, označujeme bodkou v okrúhlych zátvorkách;

(3.0) dlhšiu pauzu vyjadrujeme počtom sekúnd v okrúhlych zátvorkách;

- $\quad$ bodkou označujeme koniec zvukovo samostatného úseku reči, ak hlas hovoriaceho klesá;

, čiarkou označujeme koniec zvukovo samostatného úseku reči, ak hlas hovoriaceho mierne stúpa;

( ) pomocou prázdnych zátvoriek zapisujeme úplne nezrozumitel'né slovo;

(( )) do dvojitých zátvoriek zaznamenávame komentáre o kontexte rozhovoru, výslovnost’ a nezrozumitel'né pasáže.

$\mathrm{P}$ - podcaster, $\mathrm{H}$ - host'.
} 
P: je utorok tridsiateho prvého marca meniny má benjamína a áno aj dnes zostante sediet' doma a keby ste sa ale museli presúvat' do práce alebo do potravín, tak aj dnes bude chladnejšie, objavit' sa môže aj dážd' a na horách sneženie. denné teploty by sa mali pohybovat' niekde medzi štyrmi a deviati stupňami. počúvate dobré ráno, denný podcast denníka sme s tomášom prokopčákom a ak ste teraz doma a máte trošku času naši kolegovia so sme konferencie prichystali online kurzy na ktorých sa môžete čosi nové naučit', napríklad taký digitálny marketing. ${ }^{4}$

Pri takomto podcaste, ako uvádzame v ukážke č. 1, sa úvodné slovo s menšími obmenami opakuje aj v prípade, že tvorca podcastu je iný autor z novinárskeho kolektívu, napr.: Dobré ráno: Rómovia nie sú odolnejši voči baktériám a vírusom. Podcasty tvorené blogermi, vlogermi alebo hercami a herečkami sa vyznačujú väčšou uvol'nenost'ou, nepripravenost'ou, spontánnost'ou. Podcaster ${ }^{5}$ môže začat' formálnejším úvodom, predstavením host’a a témy podcastu, alebo tieto informácie odznejú až po prvej dialogickej sekvencii s host’om. Sprostredkovanie informácií sa diferencuje na škále od serióznej formy podania až po zábavnejšiu.

\section{Ukážka č. 2:}

P1: milé jaukyni. dnees máme pripravenú špeciálnu čast' na ktorú ja sa teším, bohužial sa neteším že som to zažila ale teším sa že o tom môžeme rozprávat' s niekým kompetentným.

P2: aa: nám sa opät' a znova podarilo do nášho tímu dostat' dana ((mienené Dana)) až z d’alekej prahy ((mienené Prahy)).

P1: wohoooo ((výkriky)). ${ }^{6}$

Opierajúc sa o klasifikáciu publicistických žánrov (podl’a J. Mistríka 1997: 466477; J. Findru 2004: 213-216) medzi podcastmi prevláda interview. Tvorca podcastu si pozýva zaujímavého host'a alebo hostí. Ide o známe osobnosti z umeleckej sféry (divadelnej, hudobnej), politikov a verejných činitel'ov, odborníkov a vedcov. Host'ami podcastov bývajú aj podnikatelia z rôznych oblastí či jednoducho úspešní l'udia.

\section{Ukážka č. 3:}

P: počúvate podgast ktorý vám prináša portal refrešer ((mienené Refresher)) a sprevádza ním fútbloger čojenko ((mienené foodbloger ČOJE)) čo som ja. do podgastu si volám

\footnotetext{
${ }^{4}$ Ukážka z podcastu Dobré ráno: Prvou obet’ou koronakrízy sú aj umelci.

${ }^{5}$ Podcaster je tvorca podcastu - analogicky ako označenia bloger, vloger.

${ }^{6}$ Ukážka z podcastu jauuu, PS: to bolelo: Život s narcistom (a prvý nahý psychológ).
} 
zaujímavých ludí a potom sa rozprávame. začneme o jedle a skončíme pri hocičom na čo máme chut'?

„V interview ide o dve veci: jednak predstavit' osobu (osobnost') a jednak autentickou formou informovat' o závažných faktoch. Interview splní obidve svoje funkcie vtedy, ked' nad fiktívnym dialógom stojí interviewujúci redaktor. Ak tak nie je, potom síce dialóg je formou prirodzeným dialógom, lenže jeho informačná nasýtenost' je nízka. Pretože váha interview leží na odpovediach, redaktor kladie provokujúce, ale súčasne tematicky usmerňujúce otázky tak, aby ich čitatel' alebo poslucháč v texte necítil“" (Mistrík 1997: 471). Vychádzajúc z tejto definície, badáme posun pri tvorbe interview $\mathrm{v}$ podcastoch. Tvorca podcastu $\mathrm{v}$ úlohe moderátora nekladie výhradne dopredu pripravené otázky, ale často reaguje spontánne a bezprostredne formuluje otázky, ktoré mu vyplývajú z prehovoru hosta. $\mathrm{V}$ jeho prejave je naznačené aktuálne premýšlanie či dotváranie myšlienky.

\section{Ukážka č. 4:}

P: určite sa dostaneme podrobnejšie k takým tým jednotlivým (.) procesom, mechanizmom .hh ale zaujíma ma ešte predtým, čo vlastne:, vy ste to už viac menej aj naznačili, ale že čo vlastne ten trh s umením robí. lebo, áno, vy ste povedali, že existujú názory, ktoré hovoria, že ved' umenie by malo byt' čisté a oprostené od peňazí od mamonu, ale na druhej strane pochopitel’ne, žijúci umelci musia z niečoho žit'. a vôbec možno dá sa povedat', čo robí trh s umením a:: a: je to vôbec ako správne položená otázka?

H: tak ja odpoviem možno nie úplne priamo, ale vy ked’ idete do lúvr ((mienené Louvre)) alebo do tejt ((mienené Tate)) alebo do akejkolvek svetovej galérie. ako sa tam ocitli tie veci? kto ich tam dal? prečo sú tam práve tieto veci? prečo tam je: práve tento obraz a prečo nie iný? prečo je tam tento autor a nie iný? ee $\mathrm{v}$ istom zmysle: dochádza: k nejakému: k nejake:j kooperacií alebo možno povedat’ aj konsenzu.

P: em dobre:, hovoríte, že treba počúvat' odborníkov, ale zoberme si, že žijeme v časoch, kedy ludia nepočúvajú napríklad lekárov, nepočúvajú klimatológov, preto: sa tak trochu obávam, alebo mám ten doje:m, že: ešte pri odborníkoch na umenie, alebo na predaj umenia, to môže byt' menej účinné. takto argumentovat'. ee dokonca si teda l'udia: k tomu môžu aj hovorit', že: čo povie odborník s umením. ${ }^{8}$

\footnotetext{
${ }^{7}$ Ukážka z podcastu Podgast by Čoje.

${ }^{8}$ Ukážka z podcastu Index: Čo robia peniaze s umením a prečo Martin Benka nedosiahne hodnoty Západu? 
Pri formulovaní otázky sa hovoriaci vracia k predchádzajúcej replike a len fragmentárne uvádza kl'účové informácie (napr. čo robí trh s umením). Časté sú vo výpovedi hezitačné zvuky (napr. ee, $\mathrm{hm}$, ehm), nadbytočné častice (napr. vlastne, proste, dobre), odchýlky v dížke hlások či nápadné predíženie krátkej samohlásky (napr. je:; nejako:m, a::). V prejave sa objavujú aj nedostatky vo výslovnosti, v gramatike. Tvorca podcastu nezvykne host'ovi „brat' slovo“ či iným spôsobom skracovat' jeho rozprávanie. Preto aj dížky podcastov sú rôzne. Nájdeme krátke podcasty s priemernou dížkou 15 minút, 24 minút, ale aj hodinové či dlhšie. Podcaster opät’ skôr spontánne vstupuje do prehovoru host'a, a tak vznikajú aj simultánne prehovory.

\section{Ukážka č. 5:}

P: karivust ((mienené Currywurst)) je vlastne vec ktorá vznikla po druhej svetovej vojne a je vlastne obyčajný nemecký vurst ((mienené Wurst)) obliatý ee: britským kečupom a: do ktorého je ešte indické in-indický ts. ehm no ten kari prášok

H: vieš čo som čítal teraz minule že mrkva

P: [no]

H: ehm tebe hovorili ked' si bol malý že: že jedz mrkvu aby si vedel pískat' alebo aby si lepšie videl

P: [no o tom o tom]

H: [alebo takto]

P: [zraku niečo viem, hej]

H: [tak]

P: [do-dostal som]

H: [vieš ako] to vzniklo celé? ${ }^{9}$

Prehovory host’a a podcastera, ako vidíme v ukážke, nie sú nijako regulované. Podcaster neplní rolu nadradeného účastníka rozhovoru, teda toho, kto sa pýta. Striedanie hovoriacich je podobné bežným rozhovorom, v ktorých komunikanti vystupujú v symetrických (rovnocenných) pozíciách (pozri Orgoňová, Bohunická 2018: 40). Nespravodajské podcasty zaznamenávajú prevažne bežnú reč ${ }^{10}$ (v zmysle každodennú). Charakteristickými znakmi takýchto podcastov sú autentickost',

\footnotetext{
${ }^{9}$ Ukážka je z podcastu Podgast by Čoje: Demotivácia: Bryndzové halušky do Bratislavy nepatria.

${ }^{10}$ Bežná reč je východiskom mnohých etnometodologicky orientovaných výskumov. „Etnometodológia skúma, ako l'udia aktívne spoluvytvárajú scény denného života, ako ich menia, či akými metódami ich udržiavajú v nezmenenej podobe“ (Lindbloom 2004: 364). Pozri aj Dolník, J. 2013.
} 
variabilnost', zrozumitel'nost', spontánnost', improvizácia a expresívnost'. Vysoká miera autentickosti vytvára dojem osobného rozhovoru, akoby hostia diskutovali „doma pri káve“. Podcast „musí byt' trochu pomalým, za každých okolností autentickým, neformálnym a úprimným. L'udia, ktorí račkujú, v ňom budú račkovat'. Tí čo hmkajú, budú hmkat'. A ked' niekto robí pri kladení otázok čudné pauzy ... nuž, bude ich robit' aj nad’alej. Lebo oni takíto sú aj naozaj. A sú to oni, kto nás bude sprevádzat' ich každodennou prácou a príbehmi, ktoré odkrývajú“ (Prokopčák 2019: nestr.). Podcasty prinášajú do sféry mediálnej komunikácie ${ }^{11}$ interview v podobe prirodzených dialógov, ktorých informačná nasýtenost' nemusí byt' nízka, ako uvádza slovenská štrukturalistická štylistika. Ponuka podcastov je vel'mi diferencovaná po obsahovej i formálnej stránke. Percipient je ten, kto hodnotí informačný prínos podcastu a dôležitým faktorom je možnost' výberu z pluralitnej ponuky mediálnych komunikátov (od profesionálnych novinárov i laikov). „Podcasty sú pre mňa presne to, čo mi v mediálnom priestore do ich objavenia chýbalo. Stíšený ten neprehl'adný, prehlušujúci zvuk sveta, ktorý k sebe pustím, len ked” chcem“ (Bajánová 2019: nestr.).

Podcasty môžeme označit' za produkty verbálnej (prevažne dialogickej) komunikácie, pre ktorú je charakteristický odklon od rečovej pripravenosti, dôslednosti či formálnej dokonalosti. Ak zohl'adníme kontextové okolnosti (médium, priestor, vzt’ah medzi diskutujúcimi a i.) a zámer vytvorit’ neformálnejšie, osobnejšie a intímnejšie rozhovory, môžeme naznačit iba isté tendencie. Tradičná žánrová a štýlová klasifikácia podl’a funkčnej štylistiky nepokrýva premenlivost' „podcastových“ interakcií.

Na tvorbe podcastu sa môžu podiel'at' aj dvaja, prípadne viacerí podcasteri, ktorí spolu diskutujú. Štýl takýchto podcastov je hovorovejší a ich informačnost' je výrazne ovplyvnená interakciou medzi podcastermi diskutujúcimi o témach, ktoré sú im blízke. V ich rozhovoroch sa objavujú aj intertextuálne presahy, ktoré nemusia byt' pre poslucháča vždy zrozumitel’né.

Monologické podcasty majú podobu komentára či referátu, v ktorom autor hovorí o nejakej téme. Vyznačujú sa pripravenost'ou a často majú podobu čítaného textu. Autor sa snaží zaujat' poslucháčov svojím verbálnym prejavom. Ide aj o podcasty, ktoré majú podobu recenzie, úvahy alebo rozprávaného príbehu. Podcaster výraznejšie pracuje so suprasegmentálnymi prostriedkami (melódia, tempo reči, prízvuk, dôraz).

\footnotetext{
${ }^{11}$ Viac o mediálnom jazyku pozri Sámelová, A., Stanková, M. 2018. 


\section{Ukážka č. 6:}

P: leto bolo v plnom prúde, priam ideálny čas vyrazit' na sibír (.) nevedela som, kam presne sa na tej sibíri vydat'. no od začiatku bolo jasné ako. a tak som skoro zrána na stanici v žiline nastúpila na vlak, aby som sa po troch dňoch cesty dotrmácala tam, kde európa končí a začína ázia. ${ }^{12}$

Pri monologickom rozprávaní podcaster pracuje s informáciami tak, aby udržal pozornost' poslucháča. Pri epizodickom pokračovaní podcast ani nemusí mat' zretel'ný záver, aby vzbudil záujem o d'alšiu čast'. Tvorbu a podobu podcastov môžu ovplyvnit' aj poslucháči svojimi komentármi. Virtuálna bezbariérovost' prekonáva vzdialenost' či časové obmedzenia spojené s fyzickým priestorom, ale aj bezprostrednú otvorenost' reakciám recipientov (Orgoňová, Bohunická 2018: 128).

\section{Záver}

V predkladanej štúdii sme sa snažili priblížit' podcast, jeho vymedzenie a charakteristické znaky ako autentickost' prejavu, spontánnost', variabilnost'. Sústredili sme sa aj na úlohu tvorcu podcastov, ktorý nie je iba moderátorom, ale aj komunikantom v symetrickom (rovnocennom) vzt'ahu s host'om. Asymetrickost' je typická pre spravodajské podcasty tvorené väčšími médiami (rozhlasom, televíziou, printovými médiami). Spravodajské podcasty sa vyznačujú aj pripravenost'ou, formálnost'ou a oficiálnost'ou. Nespravodajské podcasty tvoria predovšetkým blogeri, vlogeri, laici teda nie novinári, redaktori. Takéto podcasty sú charakteristické predovšetkým hovorovým štýlom a žánrovou hybridizáciou.

\section{Summary}

In the study, we described what a podcast is and what types of podcasts have established themselves in Slovak journalism. Percipients face a relatively new and young format, which was created thanks to the development of modern technologies. The characteristic features of podcasts are authenticity, variability, intelligibility, spontaneity, improvisation and expressiveness. The high degree of authenticity creates the impression of a personal conversation, as if the guests were discussing "at home over coffee". In monologous podcasts, which are made up of one person, on the other hand, the readiness and speech of the podcast creator is in the foreground.

\footnotetext{
${ }^{12}$ Ukážka z podcastu Ruské čajopitie: Vlakom až na Ural!
} 


\section{Literatúra}

Bajánová, N. Dajte podcastom šancu. Stačí nájst' svoju srdcovku. Dostupné z: https://podcasty.sme.sk/c/22232840/dajte-podcastom-sancu-staci-najst-svojusrdcovku-pise-nikola-bajanova.html\#ixzz62PWa4RQF (2020-04-26).

Dolník, J. Všeobecná jazykoveda. Bratislava: Veda, 2013.

Kaderka, P. Sféra mluvené mediální komunikace. In: Hoffmannová, J., Homoláč, J., Chvalovská, E., Jílková, L., Kaderka, P., Mareš, P., Mrázková, K. Stylistika mluvené a psané češtiny. Praha: Academia, 2016, s. 295-337.

Lindbloom, J. Etnometodologický prístup a príklad degradačných postupov. Sociológia - Slovak Sociological Review. 2004 (36/4), s. 361-376.

Mistrík, J. Štylistika. Bratislava: Slovenské pedagogické nakladatel'stvo, 1997.

Müllerová, O. Úlohy moderátora v rozhlasovém diskusním pořadu Radiofórum. Naše řě. 1999 (82/4), s. 169-183.

Orgoňová, O., Bohunická, A. Interakčná štylistika. Bratislava: Univerzita Komenského, 2018.

Prokopčák, T. Podcast nie je rádio, to vy si vyberáte (píše Tomáš Prokopčák). Dostupné z: https://podcasty.sme.sk/c/22232267/ako-podcasty-v-sme-takmernevznikli.html\#ixzz62PUgjqZG (2019-11-24).

Sámelová, A., Stanková, M. Some ideas on facts and no facts within media language. EJAMP. 2018 (6/2), s. 118-123.

Tvrdoň, D. Stručné dejiny podcastov, a prečo za to môže Apple. Dostupné z: https://podcasty.sme.sk/c/22232563/ako-podcasty-zacali-kratka-historiaaudioblogovania.html (2019-10-15). 